\title{
KAJIAN BIOAKTIF DAN ZAT GIZI PROPOLIS INDONESIA DAN BRASIL
}

\author{
(Bioactive compounds and nutrients content of Indonesian and Brazilian propolis)
}

\author{
Eliza Halim", Hardinsyah², Noorwati Sutandyo ${ }^{3}$, Ahmad Sulaeman², Made Artika ${ }^{4}$, dan Yahdiana Harahap ${ }^{5}$ \\ ${ }^{1}$ Apotek Duta Agung, Kompleks Pertokoan Duta Permai Blok B1 No 12 A Kalimalang Bekasi \\ ${ }^{2}$ Departemen Gizi Masyarakat, Fakultas Ekologi Manusia (FEMA), Institut Pertanian Bogor, \\ Jl. Raya Darmaga, Bogor 16880 \\ ${ }^{3}$ Rumah Sakit Kanker Dharmais, Jakarta \\ ${ }^{4}$ Departemen Biokimia Fakultas MIPA (FMIPA), Institut Pertanian Bogor. Jl. Raya Darmaga, Bogor 16880 \\ ${ }^{5}$ Departemen Farmasi Fakultas MIPA, Universitas Indonesia, Kampus UI Depok Indonesia
}

\begin{abstract}
Indonesia has a potency to produce its own propolis, however the propolis market in Indonesia is dominated by imported product, such as from Brazil. Currently, still there is no reasearch which evaluate bioactive compound and nutrient content of Indonesian Propolis (IP) compare with Brazilian Propolis (BP). The objectives of this study were to analyze bioactive compounds and nutrient contents of IP compared to BP. Bioactive compounds and nutrients content were analyzed by gas chromatography-mass spectrophotometry. The results showed both IP and BP contain fenol, a-amyrin, cylolanost, and pyrimidines. Bioactive compounds which specifically found in IP were eudesmane compound, ethyl acridine, lupeol, friedooleanan; while $B$ amyrin and cinnamic acid compound only found in BP. The nutrient contents of IP were higher than BP except for vitamin A. In conclusion, IP might have potential health benefit, similar to BP.
\end{abstract}

Key words: propolis, bioactive, nutrient

\section{ABSTRAK}

Indonesia mempunyai potensi untuk menghasilkan propolis tetapi pemasaran propolis di Indonesia didominasi oleh propolis impor seperti propolis yang berasal Brasil. Sampai saat ini belum ada penelitian yang mengungkap kandungan bioaktif dan zat gizi propolis Indonesia (PI) dibandingkan dengan propolis Brasil (PB). Oleh karena itu tujuan penelitian ini adalah untuk melakukan kajian kandungan bioaktif dan zat gizi (vitamin dan mineral) PI dibandingkan dengan PB. Komponen bioaktif dan kandungn gizi dianalisis dengan metode gas chromatography-mass spectrometry. Hasil analisis menyatakan bahwa baik PI maupun PB mengandung senyawa fenol, a-amyrin, cylolanost, dan pirimidin. Komponen bioaktif unik yang ditemukan di dalam PI adalah senyawa eudesmane, ethyl acridine, lupeol dan friedooleanan; sedangkan B-amyrin dan senyawa asam sinamat hanya ditemukan di dalam PB. Kandungan zat gizi PI lebih tinggi dari PB kecuali kandungan vitamin A. Hal ini menunjukkan bahwa PI kemungkinan mempunyai khasiat untuk kesehatan sama dengan PB.

Kata kunci: propolis, bioaktif, zat gizi

"Korespondensi: Apotek Duta Agung, Kompleks Pertokoan Duta Permai Blok B1 No 12 A Kalimalang Bekasi, Tel: 0818898781; Email: eliza.halim@yahoo.com 
Halim dkk.

\section{PENDAHULUAN}

Propolis merupakan salah satu sumber zat gizi alami dan nutraceutical yang berasal dari substrat resin yang dikumpulkan lebah dari sari tunas daun dan kulit batang tanaman yang dicampur de ngan enzim dan lilin dari sarang lebah (Galvao 2007; Lofty 2006). Propolis sudah digunakan sejak 300 SM sebagai obat untuk menyembuhkan kulit yang luka karena mempunyai efek antiinflamasi (Lofty 2006). Propolis mempunyai kandungan gizi mikro yang bernilai tinggi yaitu vitamin (A, B, dan C), mineral ( $\mathrm{Ca}, \mathrm{Mg}, \mathrm{Na}, \mathrm{Fe}, \mathrm{Mn}, \mathrm{Cu}$, dan $\mathrm{Zn}$ ), dan enzim suksinat dehidrogenase (Hegazi 1998; Bankova 2000). Kandungan aktif yang diketahui terkandung dalam propolis adalah polifenol (flavonoid, asam fenolat, dan esternya), terpenoid, steroid, dan asam amino (Bankova 2008; Kumazawa 2007). Flavonoid merupakan zat yang diketahui banyak terdapat pada tumbuh-tumbuhan dan mempunyai efek antioksidan dalam melumpuhkan radikal bebas (Manach 2004). Propolis diketahui mempunyai kandungan flavonoid yang tinggi (Bankova 2008; Kumazawa 2007). Kandungan antioksidan lainnya yang juga ditemui dalam propolis adalah vitamin A, C, E (Hegazi 1998) dan mineral Zn (Bankova 2000).

Penelitian pada hewan menunjukkan bahwa propolis mempunyai efek antimikrobial (Alencar et al. 2007; Orsi et al. 2005), antivirus (Amoros et al. 1994; Serkedjieva 1992), antifungus (Murad et al. 2002; Tosi 1996), antiparasit (Decastro et al. 1995), antiinflamasi (Ansorge et al. 2003), dan antitumor (Bankova 2005; Chung et al. 2004).

Potensi propolis di Indonesia cukup banyak sementara pasar propolis di Indonesia didominasi oleh produk impor, terutama dari Brasil. Sampai saat ini belum ada penelitian yang mengungkap kandungan bioaktif dan zat gizi propolis Indonesia dibandingkan dengan propolis Brasil. Oleh karena itu tujuan penelitian ini adalah untuk melakukan kajian kandungan bioaktif dan zat gizi (vitamin dan mineral) propolis Indonesia (PI) dibandingkan dengan propolis Brasil (PB).

\section{METODE}

\section{Desain, Tempat, dan Waktu}

PI untuk bahan penelitian diperoleh dari peternakan lebah di Wonosobo, Jawa Timur sedangkan bahan PB didatangkan langsung dari Brasil. Penelitian dilakukan pada bulan Mei 2009 sampai Maret 2011 yang terdiri atas: 1). Pembuatan ekstrak propolis Indonesia dilakukan di Laboratorium Gizi Masyarakat, FEMA, IPB, 2). Uji fitokimia dilakukan di Laboratorium Biokimia, Fakultas Matematika dan IPA, IPB, 3). Uji aktivitas antioksidan di Laboratorium Analisis Pangan, Fakultas Teknologi Pertanian, IPB, 4). Analisis zat gizi vitamin dan mineral dilaku- kan di Laboratorium Balai Besar Industri Agro (BBIA), Bogor, 5). Analisis zat bioaktif di Laboratorium Bioavailability Bioequivalent, Departemen Farmasi, FMIPA, UI, Depok dan Pusat Laboratorium Forensik, Mabes Polri, Jakarta.

\section{Tahapan Penelitian \\ Ekstraksi propolis}

Pembuatan ekstrak propolis dilakukan dengan menggunakan metode Harborne (1987) serta Anggraini (2006). Ekstraksi dilakukan secara maserasi dengan pelarut alkohol 70\%. Propolis diambil dari lebah madu (Apis melifera) yang berasal dari Wonosobo, Jawa Timur yang habitatnya pohon pinus, pohon teh, dan kaliandra di daerah pegunungan.

\section{Analisis zat bioaktif secara kualitatif}

Analisis fitokimia merupakan uji kualitatif untuk mengetahui keberadaan golongan senyawa-senyawa aktif yang terkandung dalam ekstrak propolis. Analisis fitokimia dilakukan berdasarkan metode Harborne (1987). Identifikasi yang dilakukan adalah uji flavonoid dan senyawa fenolik, uji tanin, uji minyak atsiri, uji steroid/triterpenoid, uji saponin, uji alkaloid, uji glikosida, dan uji gula pereduksi. Sampel propolis yang digunakan ialah ekstrak propolis Indonesia dan Propolis Brasil.

\section{Analisis zat bioaktif secara kuantitatif}

Analisis zat bioaktif secara kuantitatif dilakukan dengan menggunakan metode gas chromatography-mass spectrometry (GCMS). Analisis GCMS ditampilkan berdasarkan temperatur yang ditentukan, yaitu suhu pada kolom dipertahankan pada $60^{\circ} \mathrm{C}$ selama 2 menit lalu naik sampai $170^{\circ} \mathrm{C}$ dengan kecepatan $3^{\circ} \mathrm{C}$ /menit. Lalu akhirnya, suhu akan naik sampai $250^{\circ} \mathrm{C}$ dengan kecepatan $3^{\circ} \mathrm{C} /$ menit dan suhu akan stabil pada $250^{\circ} \mathrm{C}$ selama 120 menit, untuk masing-masing sampel. Penyuntikkan dilakukan pada suhu $220^{\circ} \mathrm{C}$. Gas pembawa (helium) dengan kecepatan $10 \mathrm{ml} /$ menit. Puncak yang terbentuk akan direkam untuk menghasilkan kromatogram.

\section{Uji Zat Gizi Vitamin dan Mineral Propolis}

Uji zat gizi vitamin dan mineral propolis secara kuantitatif dilakukan di Laboratorium BBIA Bogor sebagai berikut:

- Vitamin A (retinol) dianalisis dengan metode HPLC/KCKT (AOAC 960.45).

- Vitamin B1 dianalisis dengan metode HPLC/ KCKT (AOAC 968.27).

- Vitamin B2 dianalisis dengan metode HPLC/ KCKT (AOAC 970.65).

- Vitamin B6 dianalisis dengan metode HPLC/ KCKT (AOAC 2004.07).

- Vitamin C dianalisis dengan metode HPLC/KCKT (AOAC 967.21).

- Vitamin E dianalisis dengan metode HPLC/KCKT (AOAC 960.45).

- Natrium ( $\mathrm{Na})$ dianalisis dengan metode AAS 
- KCKT (AOAC 960.45).

- Natrium (Na) dianalisis dengan metode AAS (AOAC 985.35/59.1.14.2005).

- Kalsium (Ca) dianalisis dengan metode AAS (AOAC 985.35/59.1.14.2005).

- Magnesium $(\mathrm{Mg})$ dianalisis dengan metode AAS (AOAC 985.35/59.1.14. 2005).

- Besi (Fe) dianalisis dengan metode SNI.01-28961998, butir 5 .

- Tembaga $(\mathrm{Cu})$ dianalisis dengan metode SNI.012896-1998, butir 5 .

- Seng (Zn) dianalisis dengan metode SNI.012896-1998, butir 5 .

- Mangan $(\mathrm{Mn})$ dianalisis dengan metode SNI.012896-1998, butir 5.

\section{HASIL DAN PEMBAHASAN}

\section{Kandungan Bioaktif Propolis}

Hasil uji kualitatif menunjukkan senyawa yang terkandung dalam ekstrak etanol PI sama dengan ekstrak etanol PB, kecuali kandungan saponinnya dimana ekstrak etanol PI tidak mengandung saponin (Tabel 1). Unsur kimia propolis yang telah diidentifikasi oleh beberapa penelitian sebelumnya adalah flavonoid, asam fenolat, terpenoid, aldehid, alkohol, asam alifatik dan ester, asam amino, steroid, dan gula (Bankova et al. 1992; Koo et al. 1997; Kumazawa et al. 2004; Nagy et al. 1996; Park et al. 2004).

Berdasarkan uji kuantitatif, komponen bioaktif utama dalam PI adalah a-Amyrin, cyclolanost, turunan fenol (termasuk senyawa resorsinol), senyawa eudesmane, senyawa ethyl acridine, senyawa lupeol, senyawa friedooleanan, dan senyawa pirimidin. Sebagai perbandingan, komponen bioaktif utama dari BP adalah hydrocinnamic ethyl ester, a-Amyrin, B-Amyrin, cyclolanost, turunan fenol, dan senyawa pirimidin (Tabel 2).

Penelitian sebelumnya yang telah dilakukan pada PB dengan metode GCMS dan thin layer chromatography mengungkapkan komponen utama $\mathrm{PB}$ adalah komponen fenol (flavonoid, asam aromatik, dan benzopiren), di- dan tri- terpen, minyak esensial dan lainnya (Bankova 2000; Burdock 1998; Sforcin 2007). PB juga mengandung turunan asam sinamat seperti asam kafeat (3,4-hidrixycinnamic acid) dan esternya, seskuiterpen, quinones dan coumarin. Kandungan aktif pada banyak penelitian yang mempunyai efek biologis adalah Artepillin-C, PM3, CAPE, Propolin A, Propolin B dan Propolin C (Lofty 2006; Kimoto et al. 1998).

Tabel 1. Hasil Analisis Fitokimia secara Kualitatif

\begin{tabular}{clcc}
\hline No. & \multicolumn{1}{c}{ Golongan } & Ekstrak Etanol Propolis Indonesia (PI) & Ekstrak Etanol Propolis Brasil (PB) \\
\hline 1. & Flavonoid \& senyawa fenolik & ++ & + \\
2. & Tanin & + & + \\
3. & Minyak Atsiri & + & + \\
4. & Steroid \& Triterpenoid & + & + \\
5. & Saponin & + & - \\
6. & Alkaloid & + & + \\
7. & Glikosida & + & + \\
8. & Gula Produksi & + & + \\
\hline
\end{tabular}

Tabel 2. Hasil Analisis Komponen Bioaktif dengan GCMS

\begin{tabular}{clcc}
\hline No. & \multicolumn{1}{c}{ Komponen Bioaktif } & Propolis Indonesia (\%) & Propolis Brasil (PB) \\
\hline 1. & a-Amyrin & 4.32 & 2.87 \\
2. & B-Amyrin & - & 1.40 \\
3. & Cyclolanost & 15.75 & 1.81 \\
4. & 5 heptyl resorcinol & 9.33 & - \\
5. & Hydrocinnamic ethyl ester & - & 9.70 \\
6. & Fenol derivat & 0.57 & 0.47 \\
7. & Senyawa eudesmane & 0.66 & - \\
8. & Senyawa ethyl acridine & 1.93 & - \\
9. & Senyawa lupeol & 0.68 & - \\
10. & Senyawa friedooleanan & 3.92 & - \\
11. & Senyawa pirimidin & 0.81 & 0.40 \\
\hline
\end{tabular}


Halim dkk.

Berdasarkan penelitian yang dilakukan Pinto et al. (2007) pada tikus diketahui bahwa a dan $\beta$ Amyrin mempunyai efek sebagai antiinflammasi dan kadar a-Amyrin dalam PI lebih tinggi dari PB. Senyawa cyclolanost yaitu suatu senyawa saponin cycloartane yang telah diteliti oleh Shen et al. (2008) secara in vitro bersifat sitotoksik pada uji dengan human prostate tumor cell line. Kemudian Tukan (2009), menemukan bahwa senyawa cyclolanost dapat menghambat pertumbuhan bakteri yang diisolasi dari usus halus sapi. PI banyak mengandung senyawa polifenol seperti fenol ester dan senyawa resorsinol yang bermanfaat dalam pengobatan. Berbagai penelitian menunjukkan komponen fenol seperti flavonoid, asam aromatik, dan benzopiren mempunyai efek biologis yang sangat bermanfaat untuk pengobatan (Bankova 2000; Burdock 1998; Sforcin 2007).

PI mengandung suatu senyawa seskuiterpen lakton yaitu eudesmane yang bersifat sitotoksik terhadap beberapa cancer cell line (Zhang et al. 2010). Finlay et al. (1993), menemukan bahwa senyawa etil acridin mempunyai khasiat kuratif terhadap murin Lewis lung carcinoma. Saleem et al. (2001), melakukan penelitian pada senyawa triterpene lupeol dan menemukan bahwa lupeol efektif sebagai skin chemopreventive agent. Tanaka et al. (2008) melakukan percobaan pada mencit dan menemukan bahwa senyawa friedooleanan menghambat tumor kulit pada mencit. Penelitian terhadap senyawa pirimidin seperti yang dilakukan Dao dan Grinberg (1963), menemukan bahwa pirimidin berkhasiat pada pengobatan pasien kanker payudara serta berkhasiat pada pengobatan solid tumor.

Kandungan aktif PI yang diteliti oleh Syamsudin et al. (2009) berasal dari tiga tempat yang berbeda di Indonesia, yaitu Batang, Lawang dan Sukabu$\mathrm{mi}$, menemukan beberapa bahan aktif baru propolis seperti 1,3-bis(trimethylsilylloxy); 5,5-proyllbenzene; 3,4-dimethylthioquinoline; 4-oxo-2-thioxo3-thiazolidinepropionic acid; D-glucofuranuronic acid; dofuranuronic acid; patchoulene dan 3-quinolinecarboxamine.

\section{Kandungan Vitamin dan Mineral Propolis}

Berdasarkan hasil uji terbukti bahwa PI dan PB mengandung vitamin (A, C, E, B1, B2, dan B6) dan mineral (Cu, Zn, Mn, Fe, Na, Ca, dan Mg); dimana kandungan vitamin dan mineral PI lebih tinggi dari PB kecuali kadar vitamin A, dimana PB lebih besar dari PI (Tabel 3). Hasil penelitian sebelumnya menunjukkan bahwa kandungan propolis memiliki Kandungan zat gizi antara lain karbohidrat, asam amino, mineral dan vitamin (Bankova et al. 2000; Hegazi 1998) dan mineral (Ca, Mg, Na, Fe, Mn, Cu dan Zn) (Bankova et al. 2000; Syamsudin et al. 2009), juga vitamin B1, B2, B6, A, C, E, asam nikotinik dan asam pantotenik (Hegazi 1998).

\section{KESIMPULAN}

Senyawa bioaktif utama yang ada dalam PI yaitu cyclolanost, fenol derivat (termasuk senyawa resor sinol), a-Amyrin, senyawa eudesmane, senyawa etil acridin, senyawa lupeol, senyawa friedooleanan, dan senyawa pirimidin, sedangkan senyawa bioaktif dalam PB yaitu turunan asam sinamat, a-Amyrin dan B-Amyrin, cyclolanost, komponen fenol, dan senyawa pirimidin. Kandungan zat gizi vitamin dan mineral PI lebih tinggi dari PB yaitu vitamin B1, B2, B6, C, dan E dan mineral $\mathrm{Na}, \mathrm{Ca}, \mathrm{Mg}$, $\mathrm{Cu}, \mathrm{Zn}, \mathrm{Mn}$ dan Fe kecuali kadar vit A pada PB lebih tinggi dari PI.

Dari hasil dari pemeriksaan PI dan PB baik secara kualitatif maupun kuantitatif menunjukkan bahwa PI memiliki kandungan komponen bioaktif

Tabel 3. Hasil Uji Zat Gizi Vitamin dan Mineral Propolis Indonesia

\begin{tabular}{lccc}
\hline \multicolumn{1}{c}{ Parameter } & Satuan & Propolis Indonesia (PI) & Propolis Brasil (PB) \\
\hline Vitamin A & $\mathrm{IU} / 100 \mathrm{~g}$ & $<0.5$ & 445 \\
Vitamin B1 & $\mathrm{mg} / 100 \mathrm{~g}$ & 1.10 & $<0.025$ \\
Vitamin B2 & $\mathrm{mg} / 100 \mathrm{~g}$ & 2.89 & $<0.025$ \\
Vitamin B6 & $\mathrm{mg} / 100 \mathrm{~g}$ & 0.35 & $<0.02$ \\
Vitamin C & $\mathrm{mg} / 100 \mathrm{~g}$ & 5.51 & $<0.2$ \\
Vitamin E & $\mathrm{mg} / \mathrm{kg}$ & 4.09 & 0.40 \\
Tembaga $(\mathrm{Cu})$ & $\mathrm{mg} / \mathrm{kg}$ & 4.51 & 1.07 \\
Seng $(\mathrm{Zn})$ & $\mathrm{mg} / \mathrm{kg}$ & 35.2 & 1.61 \\
Mangan $(\mathrm{Mn})$ & $\mathrm{mg} / \mathrm{kg}$ & 5.98 & 0.30 \\
Besi $(\mathrm{Fe})$ & $\mathrm{mg} / \mathrm{kg}$ & 5.32 & 3.22 \\
Natrium $(\mathrm{Na})$ & $\mathrm{mg} / 100 \mathrm{~g}$ & 56.6 & 34.0 \\
Kalsium $(\mathrm{Ca})$ & $\mathrm{mg} / 100 \mathrm{~g}$ & 69.6 & 1.04 \\
Magnesium $((\mathrm{Mg})$ & $\mathrm{mg} / 100 \mathrm{~g}$ & 80.6 & 1.86 \\
\hline
\end{tabular}


dan zat gizi mineral yang sama dengan PB. Memperhatikan potensi komponen bioaktif dan vitaminmineral yang berperan sebagai antioksidan dalam PI, seperti halnya juga dalam PB perlu dikembangkan menjadi produk Traditional Indonesian Medicine dari PI. Untuk tahap selanjutnya diperlukan kajian pengembangan produk, keamanan, dan efikasi kli nisnya.

\section{DAFTAR PUSTAKA}

Alencar SM et al. 2007. Chemical composition and biological activity of a new type of Brazilian propolis: Red propolis. J Ethnopharmacol, 113(2), 278-83.

Amoros M. et al. 1994. Comparison of the antiherpes simplex virus activities of propolis and 3-methylbut-2- enyl caffeate. J Natural Products, 64, 225-240.

Anggraini AD. 2006. Potensi Propolis Lebah Madu Trigona spp. Sebagai Bahan Antibakteri. Skripsi Sarjana Departemen Biokimia, Fakultas Matematika dan IPA, IPB, Bogor.

Ansorge S, Reinhold D, Lendeckel U. 2003. Propolis and some of its constituents down-regulate DNA synthesis and inflammatory cytokine production but induce TGF-B1 production of human immune cells. Zeitschrift f "ur Naturforschung, 58c, 580-589.

Bankova VS et al. 1992. Determination of fenolics from propolis by capillary gas chromatography. J Chramtogr, 607, 150-153.

Bankova VS, de Castrob SL, \& Marcuccic MC. 2000. Propolis: recent advances in chemistry and plant origin. Apidologie, 31, 3-15.

Bankova VS. 2005. Recent Trends and Important Development in Propolis Research. Evidencebased Complementary and Alternative Med, 2, 29-32.

Bankova V, Trusheva B, \& Popova M. 2008. New developments in propolis chemical diversity studies (since 2000). Scientific evidence of the use of propolis in ethnomedicine, 2008, 1-13.

Burdock GA. 1998. Review of the biological properties and toxicity of bee propolis (propolis). Food and Chemical Toxicology, 36, 347-363.

Chung TW et al. 2004. Novel and therapeutic effect of caffeic acid and caffeic acid phenyl ester on hepatocarcinoma cells: complete regression of hepatoma growth and metastasis by dual mechanism. FASEB J, 18, 1670-1681.

Dao \& Grinberg. 1963. Fluorinated pyrimidinesin treatment of breast cancer patients with liver metastases. Cancer Chemother Rep, 1963 Mar, 27, 71-77

Decastro SL et al. 1995. Effect of different formulations of propolis on mice infected with Try- panossoma cruzi. J Ethnopharmacol, 46, 5558.

Finlay GJ, Marshall E, Matthews JH, Paull KD, \& Baguley BC. 1993. In vitro assesment of $\mathrm{N}$-[2(dimethylamino)ethyl] acridine-4-carboxamide, a DNA-intercalating antitumour drug with reduced sensitivity to multidrug resistance. Cancer Chemother Pharmacol, 31(5), 401-406

Galvao J. 2007. Biological therapy using propolis as nutritional supelemen in cancer treatment. Int J Cancer Res, 3(1), 43-53.

Harborne JB. 1987. Metode Fitokimia Edisi ke-2. (Padmawinata K, penerjemah). ITB, Bandung.

Hegazi AG. 1998. Propolis an overview. J Bee Informed, 5, 22-28.

Kimoto T et al. 1998. Apoptosis and suppression of tumor growth by artepillin C extracted from Brazilian propolis. Cancer Detect Prev, 22(6), 506-515

Koo MH et al. 1997. Investigation of flavonoid aglycones in propolis collected by two different varieties of bees in the same region. Biosci. Biotechnol. Biochem, 61, 367-369

Kumazawa S, Hamasaka T, \& Nakayama T. 2004. Antioxidant activity of propolis of various geographic origin. Food Chemistry, 84, 329-339

Lofty M. 2006. Biological activity of bee propolis in health and disease. Asia Pac J Cancer Prev, 7, 22-31.

Manach C, Scalbert A, Morand C, Remesy L, \& Jimenez L. 2004. Polyfenols food sources and bioavailability. Am J Clin Nutr, 79, 727-47.

Murad JM et al. 2002. Effect of propolis from Brasil and Bulgaria in fungicidal activity of macrophages against Parococcidiodes brasiliensis. J Ethnopharmacyl, 79, 331-334.

Nagy $M$ et al. 1996. Colorimetric determination of flavonoids in propolis. Pharmazie, 51, 100101.

Orsi RO et al. 2005. Susceptibility profile of Salmonella against the antibacterial activity of propolis produced in two regions of Brazil. J Venomous Animals Toxins, 11, 109-116.

Park JH. et al. 2004. Immunomodulatory effect of caffeic acid phenethyl ester in Balb/c mice. Int Immunopharmacol, 4(3), 429-436

Saleem M, Alam A, Arifin S, Shah MS, Ahmed B, \& Sultana S. 2001. Lupeol, a triterpene, inhibits early responses of tumor promotion induced by benzoyl peroxide in murine skin. Pharmacol Res, 43(2), 127-34

Syamsudin, Wiryowidagdo S, Simanjuntak P, \& Heffen WL. 2009. Chemical composisition of propolis from different region in Java and their cytotoxic activity. Am J Biochemist Biothech, 5(4), 180-183

Serkedjieva J, Manolova N, \& Bankova V. 1992. Anti- 
Halim dkk.

influenza virus effect of some propolis constituents and their analogues (esters of substituted cinnamic acids). J Natural Products, 55, 294-302.

Sforcin JM. 2007. Propolis and the immune system: a review. J Ethnopharmacol, 113, 1-14.

Shen T, yuan HQ, Wan WZ, Wang XL, Wang XN, Ji M, \& Lou HX. 2008. Cycloartane-type triterpenoids from the resinous exudates of commiphora opobalsamum. J Nat Prod, 71(1), 81-86

Tanaka R, Nakata T, Yamaguchi C, Wada S, Yamada T, \& Tokuda H. 2008. Potential Anti-TumorPromoting Activity of 3a-Hydroxy-D:A-friedooleanan-2-one from the stem bark of Mal- lotus philippensis. Planta Med, 74(4), 413-416

Tosi B, Donini A, Romagnoli C, \& Bruni A. 1996. Antimicrobal activity of some commercial extracts of propolis prepared with different solvent. Phytother Res, 10, 77-82.

Tukan GD. 2009. Effect of Trigona spp Propolis of pandeglang on Some Cattle Intestine Bacterial Isolateds and Analysis of its Active Components. Skripsi Sarjana Program Studi Biokimia, FMIPA, IPB, Bogor.

Zhang T, Xiao W, Gong T, Yang Y, Chen RY, \& Yu DQ. 2010. Two new eudesmane from Inula racemosa. J Asean natural product research, 12(9), 788-792. 